FINAL SUBMISSION DRAFT 30 MAY 2016

\title{
CORPORATE MOBILITY AND COMPANY LAW
}

\section{Eilís Ferran}

Globalisation has given commercial parties more freedom to choose the company law system that best suits their private needs. The growing range of techniques to facilitate choice between systems of company law reshapes the mandatory/enabling debate in countries where corporate mobility is a relatively new business phenomenon and where the past focus has mostly been on degrees of flexibility within domestic law. This article examines relocations, both out of and into the UK, as a source of learning on market preferences with respect to company law and on vulnerabilities. It considers the wider policy implications for the development of company law of more freedom of choice between company law systems. It concludes with a call to explore the potential for more optionality within company law to counter the rise of choice between systems of company law.

Keywords: corporate mobility; regulatory competition; mandatory and enabling rules; shareholder primacy

\footnotetext{
- Professor of Company and Securities Law, University of Cambridge. I am grateful to Klaus Hopt, Marc Moore, James Palmer, Carol Shutkever and Marco Ventoruzzo for comments on early versions of this work, and to the two anonymous MLR referees for their incisive reviews of the submission. Errors that remain are my sole responsibility.
}

Unless otherwise stated, all URLs were last accessed 30 May 2016. 
FINAL SUBMISSION DRAFT 30 MAY 2016 


\section{CORPORATE MOBILITY AND COMPANY LAW}

\section{(A) Introduction}

Globalisation has given commercial parties more freedom to choose the system of company law that best suits their private needs and has made where to incorporate a factor in many strategic decisions about the desired focus of a business's future operations. Whilst tax planning is a well-known and often controversial driver of business decisions by multinational companies regarding location choices, ${ }^{1}$ tax residency and place of incorporation need not necessarily go hand in hand since, with appropriate planning, they can be disaggregated (or unbundled). ${ }^{2}$ The long list of considerations that can lie behind the decision to incorporate a company in one jurisdiction rather than another thus extends far beyond taxation matters. Forming a

${ }^{1}$ H. Eidenmüller, A. Engert and L. Hornufe, ‘Where Do Firms Issue Debt? An Empirical Analysis of Issuer Location and Regulatory Competition in Europe' (2015) 41 International Review of Law and Economics 103.

${ }^{2}$ To take the UK case, whilst a company incorporated in the UK is UK tax resident (subject to certain limited exceptions), a company not incorporated in the UK will also be UK tax resident if it is centrally managed and controlled in the UK: D. Hughes, Corporate Residence (Haywards Heath: Bloomsbury Professional, 2013). UK tax residency is subject to the application of 'tiebreaker' provisions in double tax treaties, which may result in residence being allocated to a different state: ibid. 
local subsidiary may be a way for a cross-border business to overcome the lack of trust in foreign companies among customers and business partners. ${ }^{3}$ Eligibility for admission to trading on particular exchanges or market segments can be another potential driver of jurisdictional choice, ${ }^{4}$ although, as with tax residency, the incorporation location does not dictate listing location as they can be different. Public and private international law may also impinge on corporate structuring decisions, such as in relation to bilateral investment treaties where standing to claim will depend on nationality and thus may require the establishment of special purpose corporate vehicles incorporated in appropriate jurisdictions. ${ }^{5}$ Corporate location may be deliberately chosen in order to opt into (or to avoid) a particular accounting framework (notably IFRS) or a dedicated regulatory regime (such as the UK Takeover Code).

\footnotetext{
${ }^{3}$ European Commission, Proposal for a Directive of the European Parliament and of the Council on single-member private companies (2014)COM 212, 2.
}

${ }^{4} \mathrm{eg}$, third country issuers seeking admission to official listing in the EU face an extra hurdle in that they must satisfy the listing authority that the absence of home country listing is not due to a need to protect investors (implemented in the UK by the FCA Listing Rules (LR): LR 6.1.21 and LR 14.2.4). Other examples include: an issuer seeking admission to the London Stock Exchange's High Growth Segment must be a trading company incorporated in an EEA State; and the Hong Kong Stock Exchange requires issuers to be incorporated in an 'acceptable' jurisdiction and imposes additional shareholder protection requirements on those that are not.

${ }^{5}$ R. Dolzer and C. Schreuer, Principles of International Investment Law (2nd edn, Oxford University Press 2012), 52-54. 
Many jurisdictions still lack a straightforward regime for established companies to move their registered offices across borders ${ }^{6}$ but commercial practice has developed functional solutions to fill the gap, at least for more sophisticated actors that can afford to access the technology and, where moving involves separating the place of incorporation from tax residency and/or the location of listing, to absorb the ongoing costs of managing compliance with multiple regimes. Within the EU there is the possibility to transfer the registered office of an existing public company through the formation of a European Company ${ }^{7}$ or through a cross-border merger in accordance

\footnotetext{
${ }^{6}$ After consideration of the pros and cons, in December 2007 the European Commission decided that there was no need for action at the EU level. The Commission conducted a further consultation exercise on the matter in 2013 but this has not since led to regulatory action.
}

${ }^{7}$ Council Regulation (EC) No 2157/2001 of 8 October 2001 on the Statute of the European Company (SE) [2001] OJ L294/1, Art 8. By way of example, in 2011-12 the UK plc Scotty Group converted to an SE to move to Austria in order to secure cost savings and to align its legal and financial structure more logically with its geographic focus. As at end October 2015 there were over 2400 established SEs in total. The registered office and the head office of an SE must be in the same Member State: Council Regulation (EC) No 2157/2001, Art 7. The proposed Directive on single-member private limited companies (COM(2014) 212) would allow for the transfer of the registered office from one Member State to another through the formation of a single member private limited liability company (SUP) if it is allowed by the national laws of both Member States. 
with procedures giving effect to the EU Cross-border Mergers Directive. ${ }^{8}$ The transfer of a registered office can be achieved by setting up a subsidiary in the destination Member State and then merging the existing company into the subsidiary. Other alternatives lie in creative use of general mergers and acquisitions structures. One possibility is the reverse takeover, whereby a smaller company takes over a larger one and the shareholders in the target become the majority shareholders in the bidder. This structure can be used to change the location of a group holding company and has become associated with 'inversions' effected to take advantage of lower tax rates in ${ }^{8}$ Directive 2005/56/EC of the European Parliament and of the Council of 26 October 2005 on crossborder mergers of limited liability companies [2005] OJ L310/1. English cases decided under the implementing Companies (Cross-Border Mergers) Regulations 2007 (SI 2007/2974) include: Re Nielsen Holdings plc [2015] EWHC 2966 (Ch) (absorption of Dutch company by English company); Re International Game Technology Plc [2015] EWHC 717 (Ch) (merger of Italian parent into English subsidiary); Re Lanber Properties LLP [2014] EWHC 4713 (Ch) (merger of German companies into English LLP); Re Olympus Ltd [2014] EWHC 1350 (Ch) (merger of English companies by absorption into German company/SE); Re Honda Motor Europe Ltd [2014] EWHC 919 (Ch) and Re Honda Motor Europe Ltd [2013] EWHC 2789 (Ch) (mergers by absorption of Italian and Spanish subsidiaries of English company); Re Sigma Tau Pharmaceutical Ltd [2013] EWHC 3279 (Ch) (merger by absorption of Portuguese company by English sister company); Re House-Clean Ltd [2013] EWHC 2337 (Ch) (merger of English subsidiary into German parent); Re Diamond Resorts (Europe) Ltd [2012] EWHC 3576 (Ch) (Spanish subsidiaries absorbed by English company); Re Itau BBA International Ltd [2012] EWHC 1783 (Ch) (merger of Portuguese company into English company); Re Wood DIY Ltd [2011] EWHC 3089 (Ch) (merger of Italian company into English company); Re Oceanrose Investments Ltd [2008] EWHC 3475 (Ch) (merger of English and Italian companies). 
destination countries. ${ }^{9}$ Another possibility is the 'holdco scheme of arrangement', a court-supervised statutory process that enables a new holding company incorporated in the desired destination jurisdiction to be inserted at the top of an existing corporate group. ${ }^{10}$ Complex deals may involve a combination of structures, as in the case of the

${ }^{9}$ Especially by US companies, as a step to avoid paying US tax on global income. This motivation has been attributed to a number of companies that have moved from the US to the UK, such as Aon (2012), Rowan (2012) and Ensco (2010): T. Bergin, ‘Britain Becomes Haven for U.S. Companies Keen to Cut Tax Bills' Reuters Business News, 9 June 2014 at http:/ / www.reuters.com/article/us-britain-usa-tax-insightidUSKBNOEK0BF20140609. The issue acquired high political saliency: 'Even as corporate profits are as high as ever, a small but growing group of big corporations are fleeing the country to get out of paying taxes. They're keeping most of their business inside the United States, but they're basically renouncing their citizenship and declaring that they're based somewhere else, just to avoid paying their fair share.': President Obama as quoted in E.L. Talley, 'Corporate Inversions and the Unbundling of Regulatory Competition' (2015) 101 Virginia Law Review 1649, 1650. The official US response was to tighten progressively the rules governing certain tax-planning techniques: US Treasury and IRS, Notice 2014-52, Rules Regarding Inversions and Related Transactions, September 2014; US Treasury and IRS, Notice 2015-79, Additional Rules Regarding Inversions and Related Transactions, November 2015; US Treasury Fact Sheet: Treasury Issues Inversion Regulations and Proposed Earnings Stripping Regulations, 4 April 2016, at https://www.treasury.gov/press-center/press-releases/Pages/j10404.aspx. The merger of Pfizer with Allergan to move the headquarters from the US to Ireland, announced in November 2015 but scrapped in April 2016, was a casualty of the regulatory crackdown.

10 In the UK, schemes of arrangement are governed by Companies Act 2006, Pt 26. Other systems of company law in the English law 'family' have similar arrangements, eg: Corporations Act 2001, Pt 5.1 (Australia); Companies Ordinance 2014, Pt 13.2 (Hong Kong); Companies Act 2006, Pt VII (Singapore); 
Iberia/British Airways merger to create International Airlines Group (IAG), a holding company which is incorporated in Spain, has its head office in London and is premium listed on the London Stock Exchange. ${ }^{11}$ This is not to say that the majority of companies are constantly on the move - the number of companies taking advantage of these various structures is still quite low compared to the overall population of listed and quoted companies ${ }^{12}$ - but the level of activity has been sufficient to indicate that this aspect of jurisdictional corporate mobility is on the rise as a strategic choice.

Companies (Jersey) Law 1991, Pt 18A. See, generally, J. Payne, Schemes of Arrangement: Theory, Structure and Operation (CUP, 2014) ch 8.

11 The merger required, among other steps, a restructuring (via a 'hive down') of the Iberia Group, a restructuring of the BA group (via a scheme of arrangement) and the merger pursuant to the Spanish Law on Structural Modifications to Companies: Merger Project between International Consolidated Airlines Group SA and Iberia, Líneas Aéreas De España, SA and BA HoldCo SA (2010), at http://media.corporate-ir.net/media_files/irol/24/240949/mergerplan.pdf.

12 For example, the database PLC What Market. Reorganisations and Schemes. Schemes of Arrangement indicates that between 2013 and 2014 just five companies used a holdco scheme of arrangement to relocate from the UK (MXC Capital plc to Guernsey (2014); Sarossa Capital plc to Jersey (2014); Kofax plc to Bermuda (2013); Kryso Resources plc to Cayman Islands (2013); Randall \& Quilter Investment Holdings plc to Bermuda (2013)). In the same period, just two companies used equivalent Channel Islands laws to migrate into the UK (Assura Group Ltd from Guernsey (2013); Informa plc from Jersey (2013)). WPP announced a holdco scheme of arrangement in 2012, completed in early 2013 but this scheme did not change the location of the holding company (Jersey). In addition, in 2013 UMC Energy plc used a reduction of capital (without a scheme) to make a UK company the wholly-owned subsidiary 
US scholars have led the way in examining whether the extension of freedom of choice between systems of company law ('regulatory competition') is a force for good ('race to the top') or bad ('race to the bottom'), with shareholder rights as the reference point. ${ }^{13}$ EU corporate law scholarship has also embraced the theme of corporate mobility and its consequences but the European debate has tended to have a different emphasis, in part because of the persistence of certain legal barriers to cross-border mobility that are related to the 'real seat' rule of corporate recognition that is followed in the legal systems of some Member States. The Court of Justice of the European Union has played a vital role in eroding these barriers but the authorities are complex and can be hard to unravel. Gerner-Beuerle and Schillig14 have described one of the recent cases as 'a judgment that in its English version is at times barely comprehensible' and their comment that it 'introduces new subtleties and complexities' gives a flavour of the

of a Cayman Island parent. But as is clear from the text, schemes of arrangements only reveal part of the picture.

${ }^{13}$ Shareholder rights are at the heart of the 'law and finance' approach to corporate governance, whereby quantitative analysis is deployed to measure investor protection. The seminal article is R. La Porta, F. Lopez-de-Silanes, A. Shleifer and R.W. Vishny, 'Law and Finance' (1998) 106 Journal of Political Economy 1113.

${ }^{14}$ C. Gerner-Beuerle and M. Schillig, 'The Mysteries of Freedom of Establishment After Cartesio' (2010) 59 ICLQ 303. 
challenges involved in navigating a 'rules jungle'15. With so much scholarly effort going into understanding and assessing the effect of the cases, it is perhaps not surprising that questions about the broader implications of corporate mobility have sometimes been pushed into second place.

This article, though European in its geographical orientation, is not concerned with doctrinal analysis of the CJEU jurisprudence since the breakthrough Centros decision in 1999.16 Building on the rich scholarship that has traversed those complexities, the starting point here is that for larger companies, corporate mobility, for both incorporation and reincorporation, has become a reality thanks to commercial ingenuity. Practice has moved at a quicker pace than the developments in the case law. The emphasis here is therefore on the implications of this extended choice for the development of company law. The specific jurisdictional focus for this inquiry is the UK. As an EU Member State, the UK does not have an entirely free hand to adjust its company laws to keep pace with extended corporate mobility. Corporate law

${ }^{15}$ T. Biermeyer, 'Shaping the Space of Cross-border Conversions in the EU: Between Right and Autonomy: VALE' (2013) 50 CML Rev 571, 571. Also sharing the view that 'the case law on corporate mobility remains an area of considerable complexity': A. Khan, 'Corporate Mobility, Market Access and the Internal Market' (2015) 40 EL Rev 371, 389; and that 'there remain a number of conceptual difficulties: J. Borg-Barthet, 'Free at Last? Choice of Corporate Law in the EU Following the Judgment in Vale' [2013] ICLQ 503, 511.

${ }^{16}$ Case C-212/97 Centros Ltd v Erhvervs- og Selskabsstyrelsen [1999] ECR I-1459. 
regulatory capacity at the EU level is growing as can be seen from the proposed revisions to the Shareholder Rights Directive, which in addressing the exercise of voting rights, shareholder engagement, directors' remuneration and related party transactions, will to an unprecedented extent reach into matters of 'core' company law for companies that are incorporated in an EU Member State and admitted to trading on an EU regulated market. ${ }^{17}$ The implications of a shift of regulatory power to Brussels and how that could increasingly shape corporate sentiment about the attractiveness of the UK as an incorporation or listing venue are significant and require separate analysis. At this juncture, however, the pertinent point is that national policymakers retain sufficient control over the design of company law systems for it to be appropriate still to locate an inquiry into the policy implications of extended choice primarily at the domestic level.

The first substantive question that the article addresses arises from corporate emigration and concerns what the UK can learn about market preferences with respect to its system of company law as a result of this dimension of extended freedom of choice. Certain practices followed by companies that have relocated from the UK to Jersey, one of the Channel Islands, are drawn upon to inform this discussion. The article

\footnotetext{
${ }_{17}$ Directive 2007/36/EC of the European Parliament and of the Council of 11 July 2007 on the exercise of certain rights of shareholders in listed companies [2007] OJ L184/17, art 1(1) (subject-matter and scope). The proposal to revise the Directive (COM(2014) 213) is proceeding through the EU legislative process.
} 
then turns to immigration and, in particular, the 'downside' of corporate mobility from the arrival country standpoint. This part of the article considers two notorious cases where the adoption of UK corporate citizenship by essentially foreign businesses exposed weaknesses in the domestic legal and regulatory framework, and examines the policy response. But it cautions against a blinkered approach that is focused solely on the risks associated with immigration to the exclusion of its potentially benign effects. The article then turns to the wider policy implications for the development of company law of more freedom of choice between company law systems. Policymakers need to think hard about global competitiveness and the kind of corporate businesses they want to attract or retain. The natural urge to impose regulatory solutions to protect society from the harmful effects of corporate mobility has a legitimate place in the analysis of policy choices but not, it is argued, to the complete exclusion of other possibilities to ensure a rounded response both the positives and the negatives of extended corporate choice. The article concludes with a call to explore the potential for more optionality within company law to counter the rise of choice between systems. Fighting fire with fire can be dangerous but in this context it holds promise. A more choice-based approach could be expected to lessen the incentives for domestic companies to explore the options offered by expanded choice between systems. It would make the emergence of an uneven playing field - where less well-resourced companies bear the brunt of heavy-handed interventions that eventually turn out to be policy mistakes - less likely. By being more accommodating of robust governance features that are less familiar in the UK context because of the predominance of the dispersed shareholder model, it 
could be good for competitiveness. And by fostering diversity and plurality, it could help to moderate the extremes of shareholder primacy and thereby advance the fundamental policy objective for companies to achieve their social purpose.

One final introductory point. In practice and in scholarship, it is not unusual for company (or corporate) law to be interpreted in a broad way to include listing rules and capital market disclosure requirements and, often, little turns on this extended approach. After all, capital market regulation has encroached significantly on matters that, historically, would have been treated as aspects of company law. This article adopts the extended approach but with due regard to disaggregation possibilities as between company and capital market laws. When the concern is the ability of sophisticated actors to choose the combination of regimes that best suits their preferences and the ability of regulatory policymakers to maintain a coherent and effective system in the face of such extended choice, it is important to bear in mind that the choices available include the option of decoupling company and listing regimes by being incorporated and listed in different jurisdictions. ${ }^{18}$ This makes the precise connecting factors that will trigger the application of particular rules (incorporation?

\footnotetext{
${ }^{18}$ For a different take on decoupling (unbundling), which looks at the extent to which the extension of securities law into areas of corporate governance has had the unintended side effect of eroding US market power in regulatory competition in the tax field: Talley, $\mathrm{n} 9$ above.
} 
location of central management? listing? incorporation and listing?) an important part of the inquiry.

\section{(B) Emigration}

The relocation of UK companies to Jersey via a holdco scheme of arrangement provides a rich source of data on market preferences with respect to desirable features of company law. To put this data in context, the nature and extent of this activity can be outlined briefly. This section draws upon the Practical Law What's Market database on reorganisations and schemes. ${ }^{19}$

As at 20 December 2015, six of the companies included in the FTSE 100 Index were incorporated in the Channel Island of Jersey (Experian, Glencore, Randgold, Shire, Wolseley, WPP). ${ }^{20}$ Of these, Experian, Shire, Wolseley and WPP are companies with strong roots in the UK that used schemes of arrangement to relocate. Other companies

${ }^{19} \mathrm{http}: / /$ uk.practicallaw.com/7-386-8909? source=relatedcontent.

${ }^{20}$ The FTSE has its own rules for determining nationality and does not necessarily follow place of incorporation: FTSE, Determining Nationality (September 2015), at http://www.ftse.com/products/downloads/Determining_Nationality.pdf. Nationality for FTSE purposes is not rigidly tied to place of incorporation and allocation decisions are based on a range of factors including tax domicile, the location of headquarters, the location of shareholder meetings and the membership of the board of directors. 
FINAL SUBMISSION DRAFT 30 MAY 2016

outside the FTSE 100 have also used schemes of arrangement to relocate from the UK to Jersey, including the AIM traded issuer Sarossa Capital, which relocated in 2014, and the LSE premium listed issuer Cape, which relocated in $2011 .^{21}$ Tax considerations formed a common theme running through these relocations ${ }^{22}$ but it is the company law implications that are relevant here.

${ }^{21}$ Earlier examples are Velti Group (2009, Jersey (incorporation)/Ireland (tax)); Informa (2009, Jersey/Switzerland (but Informa relocated back to the UK in 2014); Beazley (2009, Jersey/Ireland (but relocated back to the UK in 2016 via a holdco scheme of arrangement); Tarsus (2008, Jersey/Ireland)); Regus (2008, Jersey/Luxembourg); Charter (2008, Jersey/Ireland); Henderson (Jersey/ Ireland); United Business Media (2008, Jersey/Ireland (but later moved tax residency back to UK).

${ }^{22}$ Experian resulted from a demerger in 2006 (from GUS plc to Argos and Experian) and its incorporation (Jersey) and tax domicile (Ireland) were deliberate choices resulting from a strategic review. Shire's relocation to Jersey (with tax residence in the Republic of Ireland) was prompted by global growth and a desire to protect the group's taxation position: Shire Press Release, 15 April 2008, at http://www.investegate.co.uk/article.aspx?id=20080415070000PC249. Wolseley, which opted for Swiss tax residency, cited tax certainty in explaining its move: Wolseley Results of Court and Scheme General Meeting 2 November 2010, at http://www.wolseley.com/index.asp?pageid=69\&newsid=11. WPP's emigration in 2008 was a direct result of concerns about the then Labour government's proposals for the taxation of foreign profits; the new Jersey holding company was tax resident in the Republic of Ireland and listed on the LSE Main Market: WPP plc Circular, 13 November 2012, 5, at http://www.wpp.com/wpp/investor/financialnews/2012/nov/13/wpp-plc-return-to-the-united/. In 2012/3 WPP used a further holdco scheme of arrangement to return its headquarters and tax residence to the UK, whilst retaining a Jersey incorporation: ibid, 11. Cape gave as reasons for its holdco scheme that a review of its corporate group structure had identified the Far East and Pacific Rim as the growth areas for 
Companies that have emigrated from the UK to Jersey have typically stressed that from a corporate law and governance standpoint it is intended to be very much 'business as usual'; an apt illustration is provided by the statement by the Chairman of Sarossa Capital in the letter to shareholders recommending its holdco scheme of arrangement that ' $[\mathrm{t}]$ here will be no substantive changes to corporate governance and investor protection measures'. ${ }^{23}$ There are many features of typical structures that support this claim. Like other foreign companies, a Jersey incorporated issuer is eligible for official listing in the UK and can apply for admission to the Main Market of the London Stock Exchange (LSE) with either a premium listing (where standards exceed the harmonised EU level) or a standard (EU-level) listing. A new applicant for premium listing is expected to have a clean trading record of at least three years but the introduction of a new holding company to a group that already has a premium listing does not engage

its business and that it had received strong support, including tax incentives, from the government of Singapore and the Singapore Economic Development Board: Cape plc Circular, 9 May 2011, 11, at http://www.capeplc.com/media/174722/capecircular_9_5_11.pdf. The scheme resulted in a Jerseyincorporated company with tax residence in Singapore and Jersey. In the case of Sarossa Capital, its Board cited Jersey's efficient fiscal regime as one of the factors behind the move: Sarossa Capital plc Circular, 20 March, 2014, 9, at http://www.sarossaplc.com/archive/circulars/GM_Circular_Notice_200314.pdf.

${ }^{23}$ Sarossa Capital plc Circular, n 22 above, 8 . 
these requirements ${ }^{24}$ and in other cases, the historical record of the existing group may suffice. ${ }^{25}$ Experian, Shire, Wolseley, WPP and Cape are all premium listed. A Jersey issuer, in common with other foreign companies, can also seek admission to the LSE's second tier market, the Alternative Investment Market (AIM), and a 'fast-track' procedure is available where a new holdco is inserted in place of an existing AIM issuer, as in the case of Sarossa Capital. ${ }^{26}$ For the purposes of oversight of its prospectuses and other market disclosures, a Jersey company, as a third country issuer, can opt into the UK regime operated by the Financial Conduct Authority (FCA); an election to have the FCA as its 'home' State competent authority enables a UK issuer that relocates to Jersey to retain EU cross-border passporting rights. All premium listed issuers (wherever incorporated) are now required to make their corporate governance disclosures by reference to the UK Corporate Governance Code. ${ }^{27}$

In addition, Jersey companies enjoy some special advantages, not generally available to foreign companies, and which reflect close historical links between the jurisdictions. CREST, the UK's securities settlement system extends to transactions in Channel Island

${ }^{24}$ LR 6.1.1A.

${ }^{25}$ LR 6.1.3D.

26 Sarossa Capital plc Circular, n 22 above, 21.

${ }^{27}$ LR 9.8.6(5)-(6) and 9.8.7. 
securities. The jurisdictional reach of the UK Takeover Code extends to offers for companies which have their registered offices in the Channel Islands and which are publicly traded on markets or trading facilities in the UK (including AIM), Channel Islands or Isle of Man. One pertinent difference is that a non-UK company must have a free float (as determined by the FTSE Ground Rules) of not less than 50 per cent to be considered eligible for inclusion in the FTSE UK Index Series, whereas the threshold for UK incorporated companies is 25 per cent. ${ }^{28}$ This may make relocation less attractive for company with a free float of less than 50 per cent. FTSE eligibility can also be a factor underlying inwards traffic to the UK from other jurisdictions. ${ }^{29}$

So far as 'core' company law is concerned, the similarities between company law in the UK and Jersey, based on their common heritage, give relocating companies a head start in claiming that it is business as usual. However, for the purposes of examining relocations as a market preference-revealing mechanism, it is the differences between the regimes and the contractual adaptations made in response to them that matter more. The Companies (Jersey) Law 1991 does not contain the full range of shareholder

${ }^{28}$ FTSE, Ground Rules for the FTSE UK Index Series (Version 12.8, May 2016), 4.4, at http://www.ftse.com/products/downloads/FTSE_UK_Index_Series.pdf; FTSE, Determining Nationality, n 20 above.

${ }^{29}$ As in the case of Polyus Gold which in 2011 used a scheme of arrangement under Jersey law to insert a UK holding company as preparation for admission to premium listing. 
rights and protections contained in the UK Companies Act 2006 but it has become standard practice for relocating companies to replicate certain UK standards by means of contractual provisions in articles of association. This practice of using contract to enshrine rights that shareholders in a UK incorporated company would normally expect to have can be viewed, in effect, as an endorsement from the market's dominant players of the UK position on these matters.

The package of special provisions included in articles of association to avoid erosion of shareholder protections typically includes ${ }^{30}$ : pre-emption rights with respect to new shares (reflecting UK Companies Act 2006, section 56131); shareholder sanction for share allotments (reflecting UK Companies Act 2006, section 551); a three-quarters majority required by special resolutions (reflecting UK Companies Act 2006, section 283) rather than the two-thirds majority mandated by Article 90 of the Jersey companies legislation and related provision with respect to majorities required for the variation of class rights; shareholder approval of ex gratia compensation payments to directors for loss of office (reflecting Companies Act 2006, sections 215-221); power for companies to request

\footnotetext{
${ }^{30}$ This paragraph draws on corporate documents accessible via the Practical Law What's Market database Reorganisations and schemes, at http://uk.practicallaw.com/7-386-8909?source=relatedcontent.

${ }^{31}$ An overseas company that is a premium listed issuer is required by the FCA Listing Rules (LR 9.3.11) to offer new shares to existing shareholders on a pre-emptive basis and must incorporate provision to that effect in its constitution (LR 6.1.25).
} 
information about the beneficial ownership of shares (reflecting UK Companies Act 2006, section 793); and information rights in favour of beneficial owners of shares (reflecting Companies Act 2006, section 146). In addition, provisions are typically included in articles to achieve a closer alignment with the UK position with respect to certain aspects of company meetings' procedures, including the right of proxies to speak and vote on a show of hands (see UK Companies Act 2006, section 324) and the rights of shareholders to require a company to circulate resolutions and explanatory statements (see UK Companies Act 2006, sections $338 \mathrm{ff}$ and 314). Articles of association typically also include requirements equivalent to the relevant provisions of the FCA Disclosure and Transparency Rules (DTR) on disclosure of interests in shares. ${ }^{32}$ The Jersey companies legislation does not contain an equivalent to the UK Companies Act 2006, section 168, which empowers shareholders to remove a director from office by passing an ordinary resolution to that effect and which is widely regarded as one of the key pillars of the British corporate governance framework. However, that gap is already closed by standard Jersey articles ${ }^{33}$ and further bespoke provision is thus not needed where they are used.

32 DTR 5, which applies to officially listed issuers (wherever incorporated) and to UK-incorporated AIM issuers.

33 Jersey (Standard Table) (Jersey) Order 1992, Art 72. 
The Companies (Jersey) Law 1991 is far more flexible than the UK Companies Act 2006 in the area of corporate capital maintenance (and has been progressively relaxed ${ }^{34}$ ), including allowing distributions to be made on the basis of a solvency statement, ${ }^{35}$ more flexible rules governing share buybacks, ${ }^{36}$ and no ban on the giving of financial assistance. ${ }^{37}$ It is not usual for the articles of a relocating company to re-impose these restrictions contractually. ${ }^{38}$ This practice is consistent with, and further reinforces, the widely-held view that the UK capital maintenance regime (which gives effect to EU law) is outdated and cannot be justified on market-mimicking efficiency grounds. The urge by relocating companies to ensure 'business as usual' so far as company law is

${ }^{34}$ Most recently by the Companies (Amendments No 11) (Jersey) Law 2014.

${ }^{35}$ Ogier, Listing Jersey Holding Companies (November 2011), at http://www.ogier.com/publications/listing-jersey-holding-companies?PDF=true.

${ }^{36}$ Mourant Ozannes, Distributions and Share Purchases and Redemptions under the Companies (Jersey) Law 1991 (September 2015), at http://www.mourantozannes.com/media/1393538/distributions-andshare-purchases-and-redemptions-under-the-companies-jersey-law-1991.pdf.

${ }^{37}$ Bedell Cristin, An Overview of Jersey Company Law (April 2011), at https://www.bedellgroup.com/siteFiles/resources/docs/insights/Briefings/Company\%20and\%20Com mercial\%20-\%20Jersey\%20Briefings/anoverviewofjerseycompanylaw.pdf.

${ }^{38}$ But special provision is included in typical articles to require the giving of financial assistance by a public company (which is not permitted by the UK Companies Act 2006) to be subject to approval by a special resolution of the shareholders. 
concerned is thus shown not to be merely a mechanical exercise: an element of positive choice as to what is valuable (and what is not) in the legal framework of the country of departure is involved. It is important to note in passing that creditor claims against existing members of a corporate group are not disturbed by the introduction of a new parent company so there is no ground for intervention to protect the interests of creditors from a midstream change to which they did not consent. Moreover, future creditors of the new Jersey holdco will be on notice that they are dealing with a Jersey company and, therefore, within the creditor protection framework of the Jersey corporate regime.

Whilst it is no surprise that departing companies leave the capital maintenance doctrine behind them, a rather more striking omission from the bespoke articles of association of relocating companies is a contractual equivalent to the UK shareholder 'say on pay' regime, comprising an annual advisory shareholder vote on the remuneration report and a binding shareholder vote at least every three years on the remuneration policy. ${ }^{39}$ The annual reports of the FTSE 100 Jersey incorporated issuers with historic links to the UK indicate that, to date, they have chosen voluntarily to follow the UK regime as a matter of good governance. The practice of voluntary adherence to the UK say on pay regime has also been adopted by some other Jersey-incorporated companies, despite the absence of direct historical links to the UK. For example, Glencore's Annual Report

\footnotetext{
${ }^{39}$ Companies Act 2006, ss 439-440.
} 
2015 notes that 'Although, as a Jersey registered company headquartered in Switzerland, Glencore is not subject to the UK's remuneration reporting regime, we consider it to be broadly reflective of good practice and have prepared this report in compliance with it, where feasible to do so' ${ }^{40}$ It was a Jersey-incorporated company, Kentz Corporation, that claimed the dubious accolade of being the first company to have its remuneration policy formally voted down; Kentz was a FTSE 250 company at the time of the vote in 2014 but it has since been taken over by the UK SNC-Lavalin Group.

A voluntary commitment based on good practice is inherently more fragile than an obligation that is hardwired into corporate constitutional documents. So far, shareholder dissatisfaction with pay has been sporadic but signs from the 2016 AGM season are that shareholders are becoming more willing to protest, especially in nonbinding votes on remuneration reports. This trend could increasingly test the resilience of a voluntary approach. That companies that have relocated to Jersey have left open the possibility to escape say on pay is a straw in the wind as to the general policy challenge posed by corporate mobility to which this article will return later. When such high-profile, and supposedly mandatory, legal requirements do not command sufficient

${ }^{40}$ Glencore Annual Report 2015, 89, at

http://www.glencore.com/assets/investors/doc/reports_and_results/2015/GLEN-2015-AnnualReport.pdf. 
market support even for investors to insist on contractual replication as part of the 'price' for their support to relocate, the essentially optional character of company law comes into sharp focus. This point has ramifications for EU, as well as UK, company law because the revised Shareholder Rights Directive is intended to put in place a mandatory say on pay regime for issuers incorporated in an EU Member States and admitted to trading on an EU regulated market that is similar to the UK model. ${ }^{41}$

But before delving further into those policy challenges, the discussion must first go in a different direction. Thus far, the focus has been on corporate mobility from the standpoint of the country of departure but extended choice between systems of company law also has implications for arrival countries. The next part of the article examines recent UK experience as a country of arrival to provide a more rounded understanding of the issues at stake.

\section{(C) Immigration}

More choice between company law systems provides new business opportunities for the arrival country but it also has the potential to make the arrival country vulnerable to new forms of opportunistic conduct that are misaligned with the public interest. Incorporation-friendly countries such as the UK run the risk of their corporate form

\footnotetext{
${ }^{41}$ See $\mathrm{n} 17$ above.
} 
being used as the vehicle of choice for illegal activities such as money laundering, tax evasion or other forms of financial crime. The recently-enacted UK Small Business, Enterprise and Employment Act 2015 contains a number of transparency-oriented measures that are aimed at protecting the UK corporate law environment from 'shell' company-related abuses of this sort. ${ }^{42}$ The Act also closes an important loophole by extending the directors' disqualification regime to allow for disqualification on the basis of foreign convictions and for conduct in relation to overseas companies to be considered as part of an evaluation of unfitness. ${ }^{43}$ On the whole, the corporate aspects of the Small Business, Enterprise and Employment Act 2015 are aimed at egregious practices that no high-quality jurisdiction would wish to condone but whether the right balance has been struck between (good) transparency and (bad) erosion of privacy that could deprive British business of legitimate investment remains to be seen.

42 Relevant corporate law aspects of the Small Business, Enterprise and Employment Act 2015 include: the abolition of bearer shares (ss 84-86); the establishment of new corporate registers of persons with significant control (ss 81-83, 'significant' being at thresholds of holding 25 per cent shares/voting rights, controlling the appointment of the majority of the board; having the right to exercise or actual exercising significant influence or control); prohibition on corporate directors (ss 87-88); and possible extension by regulation of directors' general duties to shadow directors (ss 89-91).

${ }^{43}$ Company Directors Disqualification Act 1985, s 5A and s 6 (inserted/amended by Small Business, Enterprise and Employment Act 2015, ss 104-106). 
The 'balance' question is pervasive. Take the corporate re-organisation strategies considered in the previous part. There is nothing inherently illegitimate about the use of these legal technologies for the purposes of changing corporate national identity but like all advances in legal technology, there is the potential for misuse and for unanticipated side-effects. Moreover, it is not only the lower tax revenues flowing into the public coffers that may result from corporate mobility that may be a cause for concern. Practices such as reverse takeovers and mergers to change corporate locations can generate controversy because of suspicions of use of 'back doors' to avoid normal entry standards. ${ }^{44}$ By facilitating issuer choice with respect to whether to be listed as a domestic-incorporated issuer or as a foreign issuer, commercial ingenuity can challenge policy assumptions that underpin differentiated requirements for domestic and foreign companies. And by making more likely the prospect of a greater number of footloose 'global' companies that adopt a particular national citizenship as and when, and only for as long as, it suits them, these practices risk introducing alien elements into a corporate environment that has evolved around the needs of the 'standard' domestic company. From the UK standpoint, the threat of disruption is potentially significant

${ }^{44}$ A notable area of controversy from a 'back door' entry viewpoint has been the use of reverse mergers by Chinese companies to gain entry to US markets: C.M.C. Lee, K.K. Li and R. Zhang, 'Shell Games: The Long Term Performance of Chinese Reverse Merger Firms' (2015) 90 Accounting Review 1547; M.N. Darrough, The Spillover Effect of Fraud Allegations against Chinese Reverse Mergers (January 5, 2015, at http://ssrn.com/abstract=2545685; SEC Investor Bulletin: Reverse Mergers (June 2011); C. Wu, Shortcut to the U.S. Markets through Reverse Mergers (2012) 3 Review of Business \& Finance Case Studies 43. 
because the standard features of the UK listed company - dispersed shareholders and professional managers - are not replicated in most of the rest of the world.

Whilst tensions between controlling and minority shareholders can arise within 'home grown' UK-incorporated listed companies, ${ }^{45}$ the predominance of the dispersed shareholder model of corporate ownership has resulted in a policy focus mainly on manager/shareholder agency problems. The broad corporate law environment, including listing requirements and corporate governance standards, reflects the prevailing corporate ownership pattern. However, London's success in attracting foreign listings ('foreign' for this purpose including businesses that restructure to acquire a UK holdco but which are, in substance, essentially foreign-based) has brought with it more exposure to majority/minority shareholder agency problems. ${ }^{46}$ Other

${ }^{45}$ Sports Direct International plc is a pertinent example. During 2016 Sports Direct, which has a majority shareholder (Mike Ashley) owning over 50 per cent of its shares, had its valuation cut because of governance concerns, saw revolts from independent (but minority) shareholders over directors' pay and was beset by allegations that its pay practices breached the minimum wage legislation: S. Goodley and J. Ashby, 'Revealed: How Sports Direct Effectively Pays Below Minimum Wage’ The Guardian, 9 December 2015 (online).

${ }^{46}$ R. Barker, Bumi or Bust - The Corporate Governance Implications of Foreign Issuers in London (London: IoD Big Picture, Summer 2013); R. Barker and I.H.Y. Chiu, 'Protecting Minority Shareholders in Blockholdercontrolled Companies: Evaluating the UK's Enhanced Listing Regime in Comparison with Investor Protection Regimes in New York and Hong Kong' (2015) 10 Capital Markets Law Journal 98. 
jurisdictions have had their own similar encounters with the downside of extended corporate mobility facilitated by commercial ingenuity. 47

Here it can suffice briefly to review two particularly notorious cases that revealed shortcomings in the operation of the established UK approach. ${ }^{48}$ The first involved ENRC, an essentially Kazakhstan-based business that conducted a group reorganisation in 2006 to insert a UK holdco and simplify the ownership structure of the group's assets. Thereafter, ENRC plc floated on the London Stock Exchange in 2007 and became a member of the FTSE 100 in March 2008. ENRC delisted in December 2013 after its shareholders supported a bid by its founders and the Kazakhstan government to take the company private. ENRC's listing was a turbulent episode. As a company with a small number of controlling shareholders (three founder 'oligarch' shareholders,

\footnotetext{
${ }^{47}$ eg, D.W. Puchniak and L.L. Lan, Independent Directors in Singapore: Puzzling Compliance Requiring
} Explanation (July 14, 2015). NUS Law Working Paper No. 2015/006, at http://ssrn.com/abstract=2604067 discussing the meteoric rise of S-Chips (companies that listed on the Singapore Exchange but whose operations and controlling shareholders were located in mainland China) and their propensity to collapse. The authors note that S-Chips scandals exposed weaknesses in Singapore's established system of regulation and spurred reform.

${ }^{48}$ Barker and Chiu, n 46 above , also discuss the 2014 take-private of Essar Energy, a Mumbai-based conglomerate that listed in London with controlling shareholders. Whilst Essar also faced questions about its internal corporate governance, its troubles owed much to difficult trading and political conditions and, in that sense, it is distinguishable from the cases discussed in the text. 
another Kazakh mining company and the Kazakh government) ENRC was very different from the standard UK plc. It was allowed it to list with a 'free float' (shares in public hands) of less than the 25 per cent usually required because the overall size of the offering was so large. The UK Corporate Governance Code applied to ENRC as a premium listed company but the role envisaged by the Code for independent directors (which includes independence from controlling shareholders ${ }^{49}$ ) never operated well. Tensions between the independent members of the board and the controlling shareholders were rife. ${ }^{50}$ In the assessment of one of its former independent directors, there had been a 'chronic failure to meet the governance expected of a FTSE 100 company'. ${ }^{51}$ In 2013 the UK Serious Fraud Office announced that ENRC was under investigation for allegations of fraud, bribery and corruption. When the company was taken private, the bid was at a price that its then independent directors felt materially

\footnotetext{
${ }^{49}$ Corporate Governance Code, B.1.1.
}

${ }^{50}$ One independent director voted off the board was later quoted as saying that the company should never have been allowed to float in London: R. Mason and J. Quinn, 'Sir Richard Sykes: ENRC's Walk Into the Line of Fire', The Telegraph, 11 June 2011 (online). Another ousted independent director described the company as 'more Soviet than City': G. White, R. Mason and A. Andrews, 'ENRC "More Soviet than City", says ousted board member Ken Olisa', The Telegraph, 9 June 2011 (online). Another former independent director stands accused by the company of leaking confidential information and litigation is ongoing at the time of writing: Eurasian Natural Resources Corpn Ltd v Sir Paul Judge [2014] EWHC 3556 (QBD) (interim hearing).

51 White, Mason and Andrews, n 50 above, quoting Ken Olisa. 
undervalued the business but which they nevertheless recommended the shareholders to consider it seriously because there was a lack of alternative options and imminent delisting could adversely affect liquidity, marketability and value.

The second case of ARMS/Bumi/Vallar was equally out of the ordinary. Vallar plc, an investment vehicle led by Nathaniel Rothschild, was formed in 2010 as a Jersey company and on its IPO was admitted to the standard listed segment of the London Stock Exchange as a cash 'shell'. The 'standard' segment of the market is intended to provide a 'directive minimum' (i.e. it reflects minimum standards required by EU directives) listing venue that is clearly differentiated from the enhanced standards 'premium' segment, and also sufficiently flexible to cater for a wide range of issuers (UK and foreign) and investors. ${ }^{52}$ Standard listed issuers are required to make an annual corporate governance 'comply or explain' statement by reference to the corporate governance code to which they are subject and/or the code which the issuer has voluntarily chosen to apply. ${ }^{53}$ Jersey does not have its own corporate governance code and Vallar chose to report by reference to the UK Code.

\footnotetext{
52 Financial Services Authority, A Review of the Structure of the Listing Regime (DP08/1); Financial Services Authority, Listing Regime Review (CP09/24); Financial Services Authority, Policy Statement on the Listing Regime Review (PS10/2).

${ }^{53}$ DTR 7.2.
} 
Between 2010 and 2011 Vallar acquired a number of Indonesia-based natural resource companies, in effect enabling those businesses to secure a London listing via a reverse takeover. As a result of these acquisitions, the Indonesia-based Bakrie group acquired a 47 per cent stake in the London-listed company. ${ }^{54}$ In 2011, the group was re-organised by means of a scheme of arrangement that inserted a new UK incorporated holdco (Bumi plc). Bumi then joined the London Stock Exchange with a premium listing and became the first Indonesia-focused company to enter the FTSE 100. As a UKincorporated company, the applicable FTSE eligibility requirement with respect to minimum free float was 25 per cent as opposed to the 50 per cent required of foreign companies.

During 2012 evidence of financial irregularities and allegations of value-eroding related party transactions in favour of Bakrie companies began to emerge. ${ }^{55}$ There followed a period of intense clashes between Rothschild and the Bakries. ${ }^{56}$ An acrimonious settlement in December 2013 saw the division of the group, the buy out of the Bakrie stake by another Indonesian investor, and a change of name of the remaining entity to Asia Resource Minerals plc (ARMS). However, in the face of falling coal prices, ARMS did not prosper and in 2015, after more acrimony, it was eventually taken over by Asia

\footnotetext{
54 Barker, n 46 above.
}

55 Ibid.

56 Ibid. 
Coal Ventures, a British Virgin Islands vehicle company managed by a Hong Kong based special situations hedge fund manager and funded by the corporate group of another wealthy Indonesian family. In addition, the company continued to be haunted by the events of the Bakrie period: in 2015 ARMS announced that it had reached a settlement with the FCA with regard to an investigation concerning certain related party transactions. ${ }^{57}$ The penalty of $£ 4.56$ million $^{58}$ related to three related party transactions between companies within the group and entities connected to Rosan Roeslani, a former director with links to the Bakrie family. Efforts to enforce a Singapore arbitration award obtained against Roeslani for payment of $\$ 173$ million continued. ${ }^{59}$

The sagas of ENRC and Vallar/Bumi/ARMS showed in graphic terms the negative side of the controlling shareholder ownership model: the potential weakness of independent directors vis-à-vis powerful concentrated ownership blocs, and the risk of related party

\footnotetext{
${ }^{57}$ ARMS Press Release, Financial Conduct Authority Investigation - Settlement Press Release, 17 June 2015, at http://www.londonstockexchange.com/exchange/news/market-news/market-newsdetail/ARMS/12392568.html.
}

${ }^{58}$ FCA, Final notice: Asia Resource Minerals plc (formerly Bumi plc), 12 June 2105, at https://www.fca.org.uk/static/documents/final-notices/asia-resource-minerals.pdf.

${ }^{59}$ ARMS Press Release, Result of Arbitration, 31 December 2014; ARMS Press Release, Update on Enforcement of Arbitration Award, 14 January 2015, at http://www.londonstockexchange.com/exchange/news/market-news/market-newsdetail/ARMS/12213779.html. 
transactions that extract value from the business to the detriment of minority shareholders. Perhaps mindful of the old saying that 'hard cases make bad law', in a review of the listing regime the then regulator, the Financial Services Authority (FSA), warned against treating specific concerns as representing a systemic problem. ${ }^{60}$ Nevertheless, it felt that change was needed to strengthen the position of minority shareholders - in effect, an evaluation that the 'comply or explain' corporate governance principle was not always sufficient to protect shareholders and that more prescriptive rules were needed. ${ }^{61}$

The UK listing regime was the vehicle for change, effective from May 2014. The key changes related to the listing requirements for premium listed companies with a controlling shareholder ('control' here being at the 30 per cent level). ${ }^{62}$ Under the revised listing regime a premium listed issuer, wherever incorporated, must be able to demonstrate that it carries on an independent business; ${ }^{63}$ it must have in place a formal relationship agreement with its controlling shareholder(s) and must comply with its

\footnotetext{
${ }^{60}$ FSA, Enhancing the Effectiveness of the Listing Regime (CP12/25) para 1.24. Later follow up: FCA,
} Feedback on CP12/25: Enhancing the Effectiveness of the Listing Regime and Further Consultation (CP13/15).

${ }^{61}$ FSA, CP12/25, n 60 above, para 1.26 and para 7.30.

${ }^{62} \mathrm{LR}$ 6.1.2A.

${ }^{63}$ LR 6.1.4; LR 9.2.2A(1). 
independence provisions at all times. ${ }^{64}$ The relationship agreement must impose obligations on the controlling shareholder to ensure that transactions with the company are at arms length and on normal commercial terms; and to undertake not to cause the listed company to breach or circumvent the listing rules. ${ }^{65}$ Given that companies dominated by a controlling shareholder are unlikely to take private enforcement action, the key sanction for breach of the relationship agreement is that all transactions with the controlling shareholder will become subject to prior independent shareholder approval, regardless of the size of the transaction. ${ }^{66}$

The position of independent directors of premium listed companies was also reinforced. The premium listing regime now requires that where there is a controlling shareholder, the election or re-election of independent directors must be approved by a simple majority of shareholders as a whole, and also by a simple majority of independent shareholders. ${ }^{67}$ However, if independent shareholders fail to elect or re-elect an independent director, the controlling shareholder can put to matter to a vote at a subsequent general meeting at which there is no requirement for a separate

${ }^{64}$ LR 6.1.4B; LR 9.2.2A(2); LR 9.2.2G.

${ }^{65}$ LR 6.1.4D.

${ }^{66}$ LR 11.1.1A.

${ }^{67}$ LR 9.2.2E. 
independent shareholder vote. ${ }^{68}$ So, independent shareholders can delay but not ultimately block the appointment of an 'independent' director. Furthermore, independent shareholders may be able to do little to protect a director who seeks to act in a truly independent way and, in so doing, displeases a controlling shareholder: the ability for a simple majority of shareholders to remove a director from office is protected by statute ${ }^{69}$ and is a prized part of the corporate law environment viewed from the classic UK corporate agency problem in which shareholder protection vis-à-vis management is key.

Other controlling shareholder-related changes to the listing regime that were introduced included enhanced minority protections on cancellation of listings ${ }^{70}$ or on transfers between listing categories, ${ }^{71}$ and new disclosure requirements. ${ }^{72}$ Requirements relating to reverse takeovers ${ }^{73}$ and to sponsors were also strengthened. ${ }^{74}$ Premium

${ }^{68}$ LR 9.2.2F.

${ }^{69}$ Companies Act 2006, s 168.

${ }^{70}$ LR 5.2.5.

${ }^{71}$ LR 5.4A.4.

72 LR 9.8.4-9.8.4A

${ }^{73}$ LR 5.6.

${ }^{74}$ LR 8. 
listing principles were revised to mandate equal voting within classes of shares and broad proportionality of voting to equity as between classes of shares. ${ }^{75}$ A new rule limiting eligibility to vote on matters required by the Listing Rules because the company is premium listed to holders of premium listed shares was adopted. ${ }^{76}$ However, the option of increasing the minimum free float requirement as a strategy to counteract controlling shareholders was not pursued: ${ }^{77}$ the FCA, as successor to the FSA, accepted that to do so 'could impose disproportionate burdens on all companies, when ... the vast majority of companies (including premium listed companies with controlling shareholders) are governed well. We were also warned of the risk of turning minority protection into minority control'.$^{78}$

75 Premium Listing Principles 3 and 4.

${ }^{76}$ LR 9.2.21.

${ }^{77}$ LR 6.1.19 (premium listing) and LR 14.2.2 (standard listing). The meaning of shares 'not held in public hands' was tightened (LR 6.1.19(4)/LR 14.2.2(4)) and further clarification was added to the premium listing regime on the circumstances in which the FCA would accept a percentage of less than 25 per cent in public hands (LR 6.1.20A).

${ }^{78}$ FCA, CP13/15, n 60 above, para 1.5. Also more detailed discussion in FCA, CP13/15, ch 8, where the FCA confirmed that at the premium level the more that the free float fell below 25 per cent, the weightier the evidence it would expect to have to be comfortable in granting a derogation, and also that there would be greater flexibility in the standard segment to cater for a wider range of issuers and securities. 
The FCA's comment provides the lead into the final substantive part of this article. This part has demonstrated the force of global corporate mobility as a driver of a reinforced legal and regulatory framework: in a nutshell, changes in the corporate population drew attention to weaknesses in the protection of outside shareholders that had previously been less of a worry because of the predominant ownership model; the need for reforms to improve outside shareholder protection became manifest. But the changes have not attracted universal praise. Critics of the independent business and relationship agreement requirements that were introduced into the UK listing regime in response to the corporate scandals described in this part have argued that from the point of view of encouraging engagement, these reforms are 'arguably a regressive and thus lamentable development' ${ }^{79}$ Underpinning this argument is an important point: the arrival of an 'alien species' may, on occasion, import harmful behaviours but corporate immigration, in itself, is not an adverse development that requires defensive action; indeed, such action, if insufficiently finely-tuned, could in itself have harmful effects. Different ownership models enhance the diversity of the corporate population and a particular strength of the insider, controlling shareholder model is the stronger incentive to monitor management that goes with concentrated ownership. ${ }^{80}$ From that

${ }^{79}$ M.T. Moore and E. Walker-Arnott, 'A Fresh Look at Stock Market Short-termism' (2014) 41 Journal of Law and Society 416, 444.

${ }^{80}$ R.J. Gilson, 'Controlling Shareholders and Corporate Governance: Complicating the Comparative Taxonomy' (2006) 119 Harvard Law Review 1641; M. Gelter, 'Risk-shifting through Issuer Liability and Corporate Monitoring (2013) 14 European Business Organization Law Review 498, 511-515. 
standpoint, the immigration of companies that embody the positive attributes of the concentrated ownership model begins to look rather attractive and reforms that would cause them to shun the UK take on the appearance of a policy misstep.

So what reforms to cope with both emigration and immigration? And how far should such reforms go? Law reform is not a mechanistic exercise: it involves choice on the part of lawmakers, with respect to both substantive content and the appropriate regulatory instrument to ensure that the desired segments of the corporate population (eg, domestically incorporated? domestically incorporated and listed?; listed (wherever incorporated)?) are within scope. Opportunities for sophisticated actors to engage in regulatory arbitrage between company law (in a narrow sense) and capital markets law need to be anticipated and addressed. Corporate law reforms are invariably couched in the rhetoric of maintaining global competitiveness as a business-friendly location. But fine judgments, guided by principle and informed by evidence, are needed to translate broad ideas into concrete policy that both hits the target and avoids going too far.

(D) Policy implications of extended choice between systems of company law

The growing range of transactional structures that enable private parties to choose between systems of company law discussed in the previous parts adds a new dimension 
to questions about the public policy challenges involved in shaping company law to promote business success for society's benefit. This is particularly so for legal systems outside the United States, where corporate mobility is a relatively new concept and where the focus, historically, has mostly been on degrees of flexibility within domestic law. Here the focus is the UK.

First there is the question of the policy stance with respect to the control of emigration itself. Whilst corporate 'desertion' can attract criticism because of its associations with tax mitigation strategies, from the company law angle, for the state to seek to stand in the way of properly-managed exits would be highly problematic. Proper management in this context implies a framework that caters properly for mid-stream changes that were not an implicit part of the investment bargain. Such safeguards - found in all the main procedures used to effect migration from the UK (schemes of arrangement, takeovers, cross-border mergers and conversion into an SE) - can be explained fairly easily in terms of the hypothetical bargain of rational actors since they encourage investment by providing ex ante protection against exploitation by managers or controllers. ${ }^{81}$ However, there is no convincing company law public policy justification for more extensive intervention, either at national or EU level. (It is necessary to bring in the EU dimension here because under EU law the UK could not, in any event,

${ }^{81}$ L.A. Bebchuk, 'Limiting Contractual Freedom in Corporate Law: The Desirable Constraints on Charter Amendments' (1989) Harvard Law Review 1820. 
FINAL SUBMISSION DRAFT 30 MAY 2016

unilaterally prevent a UK company from converting itself into a form of company governed by the law of another Member State to which it moves. ${ }^{82}$ )

Cross-border mobility is a strategy for businesses to manage their operational and organisational costs. As such, it is something that at a fundamental level company law policy should seek to facilitate rather than restrain. Freedom to move across borders within the community goes to the heart of the EU's market integration objective. ${ }^{83}$ The freedom for market actors to use the corporate form as a risk allocation and management tool is also deeply embedded in UK law and policy thinking. Neither statute nor caselaw has evinced much willingness to interfere with business decisions regarding the use of the corporate form except in extreme cases involving the evasion of

${ }^{82}$ Case C-210/06 Cartesio Oktató és Szolgáltató bt [2008] ECR I-9641, para 112.

83 Case C-411/03 Sevic Systems AG [2005] I-10805 [19]. This is not to ignore unease about the use of socalled 'letterbox' companies within the EU: K.E. Sørensen, 'The Fight Against Letterbox Companies in the Internal Market' (2015) 52 CML Rev 85. However, Sørensen notes that apart from the requirement for SEs to have their registered office and head office in the same MS: (Council Regulation (EC) No 2157/2001 of 8 October 2001on the Statute for a European company (SE) [2001] OJ L294/1, Art 7), general EU company law does not impinge materially on choices between systems and the problems associated with letterboxes are instead addressed via targeted interventions (such as anti-money laundering measures and the tax treatment of intra-group transactions) and regulation in specific areas of business (such as banking, where, as with SEs, head and registered offices must be in the same MS). The targeted approach is consistent with the view preferred in this text. 
existing obligations. ${ }^{84}$ For this freedom to embrace decisions about where to locate or relocate is simply a logical progression. Whilst ingenious mobility-facilitating structures that achieve commercial purposes in a tax-efficient manner may involve a certain amount of artificiality, from a corporate law standpoint that, in itself, is no reason not to sanction them. ${ }^{85}$ The stress on facilitation implies a risk that contractual or voluntary protections negotiated by stakeholders at the time of exit could prove to be weak in the face of other pressures that encourage a gradual transition towards the arrival state's system of corporate governance but that is a business and investment risk that commercial parties should be left to take for themselves. ${ }^{86}$

Secondly, corporate mobility also has policy implications beyond the specific area of emigration controls. The ramifications are multi-directional. We saw earlier that the rise of corporate mobility presents new headaches for policymakers to the extent that it

84 Prest v Petrodel [2013] 2 AC 415, [2013] UKSC 34.

${ }^{85}$ Re TSB Nuclear Energy Investment UK Ltd [2014] EWHC 1272 (Ch) [18]. How far the court has discretion on the merits of the merger is uncertain: compare Re Diamond Resorts (Europe) Ltd [2012] EWHC 3576 (Ch) [5] with Re Livanova plc [2015] EWHC 2865 (Ch) [14].

${ }^{86}$ Jennifer Hill's study of News Corporation's migration from Australia to Delaware has demonstrated that pro-shareholder concessions made at the time of reincorporation, including concessions formally incorporated into bespoke articles, can be rather quickly undermined: J. Hill, 'Subverting Shareholder Rights: Lessons from News Corp.'s Migration to Delaware' (2010) Vanderbilt Law Review 1. 
involves the arrival of new forms of harm, but it is not all gloom. One positive is that extended corporate mobility has the capacity to improve public policy by enabling its makers to be better-informed about both strengths and weaknesses within the existing framework. Regulatory competition theories allow for the characterisation of corporate mobility as a type of discovery mechanism that helps to reveal the particular mix of permissive and mandatory corporate rules that aligns best with the preferences of potential users. Findings from this discovery mechanism should improve the evidence base for policy and be a safeguard against policy error. To be clear, choices to (re)locate a company in one jurisdiction rather than another will often be driven by factors that have little to do with the contrasting features of the relevant corporate law systems. For example, it was the impact of financial regulation and bank levies, not company law, that drove the UK-based HSBC in 2015 to announce the launch of a strategic review of the best place to locate its headquarters; and it is political uncertainty rather than law that has prompted several global companies with a UK base to say that they would reconsider their position in the event of a UK exit from the EU after the referendum in June 2016. The constellation of background considerations that will inevitably lie behind corporate location or relocation decisions makes it hard to interpret such choices simply as an expression of market sentiments with respect to company law. Yet the task of pinpointing market preferences is simplified where relocation in the form of a change to corporate nationality is accompanied by the practice of cherry-picking certain features of the company law system of the country of departure and taking them along, through contract, to the country of arrival. Hence the significance of the bespoke articles adopted 
by UK companies that have relocated to Jersey, discussed earlier. As has been seen, the data largely support the shareholder orientation of company law in the UK and suggest that policy assumptions about mandatory shareholder rights being the key to long term, sustainable business success are well-aligned with market sentiments.

However, this finding also points towards a conundrum. The market - that is, its dominant actors - may indeed like the strong shareholder orientation of UK company law and support further strengthening but it has become highly contestable whether the overarching public policy objective that underpins company law - to help create an environment in which business can flourish for the benefit of society as a whole ${ }^{87}-$ is best served by corporate law models that are strongly shareholder-centric in their orientation. $^{88}$ Revealed market preferences provide empirical content for policy decisions but irrespective of whether policy actors use the hypothetical bargaining model or regulatory paternalism as their guiding principle, the job is not simply about

${ }^{87}$ H. Hansmann and R. Kraakman, ‘The End of History for Corporate Law' (2001) 89 Georgetown Law Journal 439, 441. But note W.W. Bratton and M.L. Wachter, 'Shareholders and Social Welfare' (2013) 36 Seattle University Law Review 489 who challenge the conventional linkage in the legal literature between shareholder value maximisation and social welfare maximisation.

${ }^{88}$ Bratton and Wachter, $\mathrm{n} 87$ above, contend (at 525-526) that 'Shareholder value enhancement certainly impacts economic efficiency. But ... any connection between corporate politics and social welfare enhancement is at best tenuous and at worse regressive'. Contrast L.A. Bebchuk, 'The Case for Increasing Shareholder Power' (2005) 118 Harvard Law Review 833. 
codifying market practice. ${ }^{89}$ Market endorsement notwithstanding, there is a danger that reforms aimed at strengthening shareholder rights could actually be counterproductive in terms of overall social welfare in that they could simply add to the armoury of activists that put pressure on managers to pursue policies that produce short term gains but which are value destroying in the longer term. ${ }^{90}$

Whilst criticism of shareholder primacy and shareholder power is not new and has generated an enormous body of literature, concerns have mounted in the face of a rising proportion of company profits being paid out to shareholders notwithstanding sluggish economic conditions and social tensions flowing from austerity policies. ${ }^{91}$ There is concern around the world about the tension between the short term profit horizons of modern equity investors and the long term investment that is required for sustainable

\footnotetext{
${ }^{89}$ M.T. Moore, ‘Private Ordering and Public Policy: The Paradoxical Foundations of Corporate Contractarianism' (2014) 34 OJLS 693, 727-8.
}

${ }^{90}$ W.W Bratton and M.L. Wachter, 'The Case Against Shareholder Empowerment' (2010) 158 University of Pennsylvania Law Review 653.

${ }^{91} \mathrm{eg}$ the Chief Economist of the Bank of England, Andy Haldane, has drawn attention to the fact that in the 1970s only 10 per cent of company profits were returned to shareholders but that this figure is now 60-70 per cent: quoted in K. Rawlinson, 'Shareholders Receive Too Much Money from Business- Bank's Chief Economist' The Guardian, 25 July 2015 (online). 
FINAL SUBMISSION DRAFT 30 MAY 2016

economic growth. ${ }^{92}$ Negative depictions of shareholder power abound. ${ }^{93}$ For the UK, which has a system of company law that arguably outstrips even the US in the extent of its pro-shareholder orientation, ${ }^{94}$ the concerns are significant. The 'welfare revolution' signalled in 2015 by the recently-elected Conservative government threatens a fundamental re-evaluation of the social contract that, it is claimed, provided the conditions in which shareholder primacy could thrive without too much of a backlash from other quarters. ${ }^{95}$

92 S.J. Terry, 'The Macro Impact of Short-Termism' (2015), at http://economics.mit.edu/files/10386; L. Stout, 'New Thinking on Shareholder Primacy' (2012) 2 Accounting, Economics and Law 2152 (claiming that shareholder primacy thinking in its conventional form is on the brink of intellectual collapse); J.C. Coffee and D. Palia, 'The Wolf at the Door: The Impact of Hedge Fund Activism on Corporate Governance' (2016) 1 Annals of Corporate Governance 1 (hedge fund activism may be leading to a broad and systemic shift by American corporations from investment to payout and in particular towards avoidance of investments in R\&D).

${ }^{93}$ J.G. Hill, 'Images of the Shareholder - Shareholder Power and Shareholder Powerlessness' in J.G. Hill and R.S. Thomas (eds) Research Handbook on Shareholder Power (Cheltenham: Edward Elgar Publishing, 2015).

${ }^{94}$ C.M. Bruner, 'Power and Purpose in the "Anglo-American" Corporation' (2010) 50 Virginia Journal of International Law 579.

95 The ascendancy of shareholder primacy in the US has been linked to changes in the pension system, specifically the rise of defined contribution schemes that have made more of the workforce dependent on stock market performance: M. Gelter, 'The Pension System and the Rise of Shareholder Primacy' (2013) 43 Seton Hall Law Review 909. The strength of the link between pensions and the position of shareholder 
The rise of corporate mobility intersects with the debate about the social purpose of companies and the excesses of shareholder power at a particularly sensitive point. Generally speaking lawmakers do show considerable robustness in the face of opposition to reform, including opposition that is linked to relocation threats. Aspirations for 'modern law that provides maximum freedom for participants to perform their proper functions', 96 and an emphasis 'in favour of facilitating markets' and 'against interventionist legislation', ${ }^{97}$ do not translate into a laissez-faire approach of extreme deregulation. Public policy reflects a strong conviction that safeguards are perfectly compatible with, and necessary for, the achievement of, the goal of making a jurisdiction a globally attractive place to set up and run a business, the reasoning being that this approach will both attract issuers that want to bond with a high-quality regime and give investors the confidence they need in order to be persuaded to part with their money. Nevertheless, the rise of corporate mobility reinforces the need for policymakers to proceed with caution. Within the policy process, due weight must be

primacy, with implications for the location of political support for its further enhancement, is relevant to the UK where the pension system has shifted decisively away from defined benefit (final salary) to defined contribution schemes.

${ }^{96}$ Company Law Review Steering Group, Modern Company Law for a Competitive Economy: The Strategic Framework (1999), v (executive summary).

${ }^{97}$ Ibid. 
given to the consideration that, in the end, sophisticated actors have the option to neutralise reforms through strategic moves to other, more amenable, jurisdictions. For such actors, company law is indeed anchored in the world of supply and demand and is essentially contractual in character. ${ }^{98}$ It follows that it will be the less sophisticated (or, more bluntly, less well-resourced) actors that will bear the brunt of changes that, in the long run, could turn out to be policy mistakes.

Starting from the premise that for better or worse, the UK system of company law is shareholder-centric and that this orientation is unlikely to change any time soon, is there any scope for proposals that have the aim of curbing the negative externalities of shareholder short-termism to gain traction in a world of extended choice? Can we extract anything from the study of corporate emigrations and immigrations in this article to help address this question? This may depend on how the strategic policy choices are framed. If they are focused narrowly on the scope to impose regulatory requirements to rein in shareholders, corporate mobility looks like a problem and not a solution because sophisticated actors have the option to find ingenious ways round imposed requirements. Yet the issues do not need to be so narrowly circumscribed. Another potentially promising strategy is to recall the essentially facilitative character of company law, and to reaffirm its centrality to policy development: more choice within company law could also make a valuable difference. To explain what may appear to be

98 Compare Moore, n 89 above, 708-710. 
a jarring and even heretical suggestion, let's recall from earlier that whilst immigration can bring new problems, it also has the potential to foster beneficial diversity. The necessarily complex trade-offs involved in the policy response to corporate mobility (both inwards and outwards) should therefore include thinking hard about how the UK can adapt its laws to increase its attractiveness as a location for companies that embody the best features of a plurality of ownership models because this is an exercise that, in time, could help to change the corporate ecosystem for the benefit of society as a whole.

That the UK ecosystem needs to change derives powerful support from The Purposeful Company, a report in May 2016 by the Big Innovation Centre, an organisation of leaders from the worlds of business, politics and academia that seeks to develop practical policy proposals around values of purpose and inclusivity to rebalance and grow the economy. ${ }^{99}$ The report identifies 'purpose' as being key to corporate and economic success. It notes that 'The British ecosystem militates against purposeful companies with its uniquely fragmented, diversified shareholder base, a particular legal and regulatory system that imposes short term profit maximisation on company boards, and too few forces that counteract these tendencies'. ${ }^{100}$ It calls for redesign around four elements pivotal to the delivery of corporate purpose: ownership, governance, the

99 http://www.biginnovationcentre.com/media/uploads/pdf/The\%20Purposeful\%20Company\%20Interi m\%20Report.pdf 100 Ibid, 4. 
ecosystem in which firms operate and the business model the company chooses to operate. This article has gone on a global trip to arrive at a similar position. Policy options outlined in that report overlap to an extent with two specific examples that can be explored briefly here to make the pro-choice hypothesis more concrete.

First, take the idea of countering short-termism and rewarding long term shareholding through the conferral of additional voting rights (loyalty shares) or, at a more general level, the use of dual class or other control-enhancing ownership structures. UK company law is permissive with regard to departures from the proportionality principle. $^{101}$ Furthermore, there is optionality within the listing regime in that companies with complex ownership structures have the choice to apply for standard listing with their existing control-enhancing devices or to restructure to meet the shareholder equal voting, proportionality and equal treatment requirements for premium listing. ${ }^{102}$ But the exclusion of companies with complex ownership structures from the more prestigious premium segment is symptomatic of a continuing significant

\footnotetext{
${ }^{101}$ M. Moore and P. Gillyon, '"Loyalty Shares" and Weighted Voting Rights in Companies Formed and Registered Under the Companies Acts' [2015] Butterworths Journal of International Banking and Financial Law 334.
}

102 LR 7.2.1A; Premium Listing Principles 3-5. 
degree of distaste for departures from one-share-one-vote within UK policy circles. ${ }^{103}$ This stance, reinforced by the post Bumi/Vallar changes to the UK listing regime, 104 reflects assumptions about the innate superiority of shareholder proportionality that in principle are now open to question. Complex ownership structures are prone to certain types of agency concerns, it is true, ${ }^{105}$ but the shareholder engagement debate demonstrates that the one-share-one-vote norm is hardly problem free either. Studies on the value-enhancing effects of dual class or other controlling-enhancing structures

${ }^{103}$ BIS, Practical and Legal Issues Related to Limiting the Rights of Short-term Shareholders Suring Takeover Bids (BIS Roundtable, October 2014, at https://www.gov.uk/government/uploads/system/uploads/attachment_data/file/367140/bis-141159-note-of-bis-roundtable-issues-related-to-limiting-the-rights-of-short-term-shareholders-duringtakeover-bids.pdf) para 11 (noting that UK company law is sufficiently flexible to permit loyalty based ownerships structures to reward long term shareholding, should companies and their shareholders wish to introduce them, but that there is little demand for, and indeed significant opposition to ,such approaches from both companies and investors, at least with respect to publicly traded company equities).

${ }^{104}$ By, in particular, the introduction of the Premium Listing Principles and LR 9.2.21, which limits eligibility to vote on matters relevant to premium listing to holders of shares admitted to premium listing. The FCA explained that the purpose was to 'dis-incentivise the creation of artificial structures involving multiple classes with different voting powers designed to allow control to rest with a small group of shareholders': CP13/15, n 60 above, para 2.25.

${ }^{105}$ R. Masulis, C. Wang and F. Xie, 'Agency Problems at Dual-Class Companies' (2009) 4 Journal of Finance 1697. 
can be found. ${ }^{106}$ As Ventoruzzo has noted with particular reference to Italy, old taboos around multiple voting shares are disappearing - pertinently under exactly the sort of competitive pressures discussed in this article, with the ability to create loyalty share structures having been a key driver of the Fiat migrations to the Netherlands. ${ }^{107}$ The UK could go further in this regard - not to force companies into control enhancement structures (the example of the controversial French Florange law serves a salutary example in that respect $\left.^{108}\right)$ - but to be even more accommodating of choice at the company level. ${ }^{109}$ As well as potentially rethinking the Premium Listing Principles, this re-adjustment could mean looking again at shareholder voting entitlements. Loyalty

106 Barker and Chiu, n 46 above, provide an overview.

${ }^{107}$ M. Ventoruzzo, The Disappearing Taboo of Multiple Voting Shares: Regulatory Responses to the Migration of Chrysler-Fiat (March 5, 2015). Bocconi Legal Studies Research Paper No. 2574236; Penn State Law Research Paper No. 3-2015; ECGI - Law Working Paper No. 288/2015, at http://ssrn.com/abstract=2574236. J. Delvoie and C. Clottens, 'Accountability and Short-termism: Some Notes on Loyalty Shares' (2015) 9 Law and Financial Markets Review 19.

108 The Florange Law, introduced in 2014, automatically grants double voting rights from 2016 to shares registered for more than two years. There is an opt out but the high threshold (a two-thirds vote) gives it a very strong default character.

${ }^{109}$ Delvoie and Clottens, n 107 above, 24 (supporting the idea of letting companies experiment with loyalty shares). See also L.L. Dallas and J.M. Barry, 'Long-term Shareholders and Time-Phased Voting' (2015) 40 Delaware Journal of Corporate Law (forthcoming). 
share structures can involve the use of a class of shares that is not itself listed ${ }^{110}$ but under the revised premium listing regime eligibility to vote on matters relevant to premium listing is limited to holdings of premium listed shares. ${ }^{111}$

Or, secondly, to go to the very heart of company law, take the issue of the perverse consequences that some have associated with the much debated duty to promote the success of the company for the benefit of its members (Companies Act 2006, section 172) - ie that contrary to what was intended, it may have actually reinforced in practice a short-term shareholder value maximisation version of shareholder primacy that is detrimental to society. ${ }^{112}$ The Kay Review of UK equity markets and long-term decision making reported that even though section 172 could not, in its view, be equated with a responsibility to maximise the current share price 'we received evidence that some company directors thought that it could'. ${ }^{113}$ The post-financial crisis debate

110P. Bolton and F. Samama, L-Shares: Rewarding Long-Term Investors (November 1, 2012). ECGI Finance Working Paper No. 342/2013, at http:/ / ssrn.com/abstract=2188661.

${ }^{111}$ LR 9.2.21.

112 D. Collison, S. Cross, J. Ferguson, D. Power and L. Stevenson, Shareholder Primacy in UK Corporate Law: An Exploration of the Rationale and Evidence (London: Association of Chartered Certified Accountants, 2011) 34 .

113 J. Kay, The Kay Review of UK Equity Markets and Long-tern Decision Making: Final Report (London: BIS, July 2012) 17. 
around the need to revisit the duties of directors of banks revealed considerable scepticism about section 172 as an effective mechanism to curb the incentives for directors to pursue leveraged short-term strategies for the benefit of shareholders at the expense of society. ${ }^{114}$ Although some evidence of section 172 as a driver of change has been found, 115 the assessment in recent academic literature has been rather negative as to the overall impact of the much-vaunted 'enlightened shareholder value' concept as something significantly different from the classic shareholder value approach. ${ }^{116}$ The Big Innovation Centre's Purposeful Company Report is also sceptical as to its practical impact. ${ }^{117}$

114 eg, Parliamentary Commission on Banking Standards, Changing Banking For Good (HL Paper 27-II, HC 175-II) paras 173-175.

${ }^{115}$ A. Keay and R. Adamopoulou, 'Shareholder Value and UK Companies: A Positivist Inquiry' (2012) 13 European Business Organization Law Review 1.

${ }^{116}$ N. Grant, 'Mandating Corporate Environmental Responsibility by Creating a New Directors' Duty' (2015) 17 Environmental Law Review 252, 256 ('far from implementing an enlightened approach to the role of the corporation, the post-2006 company law regime has, in fact, simply reverted to shareholder primacy in its most basic form'); N Grier, 'Enlightened Shareholder Value: Did Directors Deliver?' (2014) 2 Juridical Review 95 (describing s 172 as a failure and analogising it to 'like patting a wolf on the head and asking it to be good' (at p 108).

117 n 99, 125. 
More flexibility within company law could, again, hold promise as a way forward. When what became section 172 was first proposed, the thinking was that it was important to make the success duty expressly subject to the company's constitution, the reasoning behind that being 'it should be possible for the constitution of the company to limit and define the way in which this duty is to be carried out ... It is for the constitution, and decisions under it, to lay down as appropriate the success-model of the company and the members will be bound by this'.118 Section 172(2) expresses in a weak way the possibility to adapt the duty to reflect corporate purpose. Perhaps it is time to return to the matter and to consider making it clearer that companies do have the option to determine their own success model and that doing so will shape the operation of section 172 ? If nothing else, this would remove the possibility for market participants to characterise section 172 as an exogenous factor that forces short-termist behaviour regardless of internal preferences. Reform in this direction could potentially do the same job as proposals to introduce alternative types of business vehicle (such as the benefit corporation ${ }^{119}$ or the trust corporation ${ }^{120}$ ) but arguably with less disruption.

${ }^{118}$ Company Law Review Steering Group, Developing the Framework (URN 00/656, 2000), para 3.49.

${ }^{119}$ One potential advantage of the adoption of a specific alternative business form is that the provision of a clear 'menu' of different models with pre-defined features may overcome barriers that inhibit private contracting: J.E. Hasler, ‘Contracting for Good: How Benefit Corporations Empower Investors and Redefine Shareholder Value (2014) 100 Virginia Law Review 1279. On the other hand, a proliferation of different and potentially untested business models could bring with it new, unanticipated and unintended issues. Early examination has suggested significant deficiencies in the benefit corporation reporting framework: J. Haskell Murray, 'An Early Report on Benefit Reports' (2015) 118 Virginia Law 
One obvious weak spot of suggestions to explore the scope for more optionality within the UK system is that this could be a rather pointless exercise if there is little or no demand for it among companies and investors. But there are sufficient prominent voices calling for a different type of capitalism to suggest that the effort could be worthwhile. Perceptions as to what constitutes 'best practice' can change. A facilitative approach is at least preferable to the alternative of attempting to force change in difficult areas through heavy-handed intervention. From the corporate mobility standpoint, a virtuous circle whereby enhanced optionality improves the UK's ability to attract and/or retain well-run global companies with different ownership structures and that, in turn, fosters more ownership diversity among domestic companies can be envisaged.

\section{(E) Conclusion}

The prospect of losing business through corporate emigration may not currently weigh too heavily on the minds of those responsible for shaping company law policy in the

Review 25., The establishment of new business forms may be unnecessary if the reforms needed to facilitate diverse success models can be achieved within the existing unitary, yet flexible, corporate law framework.

${ }^{120}$ C. Mayer, Firm Commitment (OUP 2013). 
UK (or for contributing the UK's views to the development of company law at the EU level). The number of companies migrating from the UK remains tolerably low, and (helped by a favourable tax regime) there is traffic the other way to attenuate the impact of emigration. ${ }^{121}$ The popular association of corporate migration with tax or regulatory avoidance creates reputational disincentives that should militate against the risk of mass exodus in the immediate future. ${ }^{122}$ There is also the practical matter of costs, including exit taxes associated with the moving of tax residency, which remain permissible and so add to the price of exit. ${ }^{123}$ Where the effect of corporate mobility is disaggregation or unbundling of the governing corporate, tax and/or listing regimes,

${ }^{121}$ Some companies (eg Fiat) have just moved their tax base to the UK whilst retaining foreign corporate nationality but others (eg Noble Corpn, which moved from Switzerland to the UK in 2013 (having moved to Switzerland from the Cayman Islands in 2009; and also the formerly US companies mentioned in n 9 above) have also changed their corporate nationality. Changes in UK taxation drove Beazley's return to the UK in 2016, n 21 above.

${ }^{122}$ Since UK companies are tax resident in the UK by virtue of incorporation, a change of corporate nationality would be needed to migrate to a different tax regime (subject to double tax treaties).

${ }^{123}$ Case C-371/10 National Grid Indus BV v Inspecteur van de Belastingdienst/kantoor Rotterdam [2011] ECR I12273 where the Court decided that the imposition of an exit tax is not, of itself, contrary to EU law (subject to proportionality). This decision has been reaffirmed since: Case C-38/10 Commission v Portugal. But exit charges that go beyond what is necessary to achieve the objective of preserving the coherence of the domestic tax systems and the balanced allocation of taxation powers are not permitted: Case C-64/11 Commission v Spain; Case C-261/11 Commission v Denmark. 
the ongoing compliance costs may be especially significant. Nevertheless, it would be myopic not to acknowledge that as the options to escape through reincorporation expand, the discretionary policy space must inevitably become more constrained.

The rise of corporate mobility performs a valuable function by refocusing attention on the enabling/mandatory balance within company law. Corporate mobility erodes legal immutability - at least for the sophisticated actors who can afford to access the relevant technologies and live with the consequences of operating under multiple legal regimes. Fighting fire with fire can be dangerous but in this context it may hold a key to ensuring continued policy effectiveness. Exploring the possibilities for more optionality within company law (broadly interpreted) holds considerable promise. Done well and with appropriate safeguards to contain the inevitable downside risks, this approach could be expected to lessen the incentives for domestic companies to explore the options offered by expanded choice between systems. It would make the emergence of an uneven playing field - where smaller (ie less well-resourced) companies bear the brunt of heavy-handed interventions that eventually turn out to be policy mistakes - less likely. By being more accommodating of robust governance features that are less familiar in the UK context because of the predominance of the dispersed shareholder model, it could be good for competitiveness. And, crucially, by fostering diversity and plurality, it could help to moderate the extremes of shareholder primacy and thereby advance the fundamental policy objective for companies to achieve their social purpose. 
This is not, it is worth emphasising, a battle cry for mass deregulation - company law requires a significant mandatory element - but the appropriate combination of mandatory and enabling rules is not static and must evolve in response to changing market conditions, such as the growth of extended choice between systems of company law. And, notwithstanding the rise of new factors, it is not breaking new ground to stress the merits of a facilitative and flexible approach to company law. As the review group that led the reforms that became the UK Companies Act 2006 explained: 'there is an almost infinitely diverse range of businesses and business philosophies and there needs to be a correspondingly wide variety of systems of company governance. These systems must be free to develop in changing economic, social and technological conditions. In providing an optimal climate for disciplined and efficient governance, company law must encourage, not suppress, this variety and flexibility.' ${ }^{\prime 24}$ Recent calls for a more flexible UK system that would encourage companies to consider divergent control structures (to quote Martin Wolf of the Financial Times: 'let 100 governance flowers bloom' ${ }^{125}$ ) are a sign that these aspirations have not been met. There is unfinished business.

${ }^{124}$ Company Law Review Steering Group, Developing the Framework , n 118 above, para 2.6.

${ }^{125}$ Martin Wolf, Opportunist Shareholders Should Embrace Commitment (Keynote speech, ICGN Conference, London 2015), at https://www.icgn.org/sites/default/files/Martin\%20Wolf\%20speech.pdf. 
FINAL SUBMISSION DRAFT 30 MAY 2016 